\title{
Influence of environmental enrichment on the rehabilitation of white-eyed parakeet (Psittacara leucophthalmus)
}

\author{
Influência do enriquecimento ambiental na reabilitação de Periquitão-maracanã (Psittacara
}

leucophthalmus)

Influencia del enriquecimiento ambiental en la ehabilitación Calancate ala roja (Psittacara

leucophthalmus)

Received: 12/02/2021 | Reviewed: 12/08/2021 | Accept: 12/13/2021| Published: 12/21/2021

\author{
Gabriela Cortellini Ferreira Ramos \\ ORCID: https://orcid.org/0000-0002-1953-4905 \\ Universidade Estadual Paulista, Brasil \\ E-mail: g.cortelliniferreira@gmail.com \\ Sergio Diniz Garcia \\ ORCID: https://orcid.org/0000-0002-5848-0516 \\ Universidade Estadual Paulista, Brasil \\ E-mail: sd.garcia@unesp.br \\ Matheus Janeck Araujo \\ ORCID: https://orcid.org/0000-0002-6588-4578 \\ Universidade Estadual Paulista, Brasil \\ E-mail: mathjaneck@hotmail.com \\ Márcia Marinho \\ ORCID: https://orcid.org/0000-0003-2177-6214 \\ Universidade Estadual Paulista, Brasil \\ E-mail: marcia.marinho@unesp.br
}

\begin{abstract}
The use of sensory, physical, cognitive, and alimentary stimuli are varieties of environmental enrichment used to minimize stress caused by the monotonous captive environment. The objective of this study was to verify the impact of environmental enrichment in escape-related behavioral stereotypies. Thirty birds of the species Psittacara leucophthalmus were observed from March to September 2016, received at the Wild Animal Recovery and Screening Center of the São Paulo State University (UNESP), School of the Veterinary Medicine campus Araçatuba. The methodology used for the behavioral observations was the focal animal with observation through filming were made by 18 hours per bird for three consecutive days, while physical, cognitive, food, and sensory enrichment methods were applied, and the assessment was carried out before, during, and after the application of environmental enrichment. The data were analyzed by the Shapiro-Wilk test for normality and by the Friedman test, which showed no significant difference ( $\mathrm{p}>0.05$ ) before, during, and after environmental enrichment. Despite the statistical analyses, the perception of the bird's welfare improving was visually clear.
\end{abstract}

Keywords: Wild bird; Stereotyped behavior; Welfare animal.

\section{Resumo}

A utilização de estímulos sensoriais, físicos, cognitivos e alimentares são formas de enriquecimento ambiental, com objetivo minimizar o estresse decorrente do ambiente monótono do cativeiro. O objetivo deste estudo foi verificar o impacto do enriquecimento ambiental nas estereotipias comportamentais relacionadas à fuga. Foram observadas 30 aves da espécie Psittacara leucophthalmus, no período de março a setembro de 2016, recebidas no Centro de Recuperação e Triagem de Animais Silvestres da Universidade Estadual Paulista (UNESP), Faculdade de Medicina Veterinária do Campus de Araçatuba. Como metodologia utilizada para a observação do comportamento utilizou-se a técnica de animal focal obtida por filmagem, perfazendo um total de 18 horas/ave, durante três dias consecutivos, sendo utilizados no primeiro dia o método físico e cognitivo; no segundo o alimentar e físico e no terceiro o sensorial. Os dados foram analisados inicialmente pelo teste Shapiro-Wilk e posteriormente pelo teste de Friedman, demonstrando que não houve diferença significativa $(\mathrm{p}>0,05)$ nos momentos antes, durante e após o enriquecimento ambiental, embora tenha sido nítida a percepção da melhoria do bem-estar das aves.

Palavras chave: Aves selvagens; Comportamento estereotipado; Bem-estar animal.

\section{Resumen}

El uso de estímulos sensoriales, físicos, cognitivos y dietéticos son formas de enriquecimiento ambiental, con el objetivo de minimizar el estrés derivado del monótono ambiente de cautiverio. El objetivo de este estudio fue verificar el impacto del enriquecimiento ambiental sobre los estereotipos conductuales relacionados con la fuga. Se observaron 
treinta aves de la especie Psittacara leucophthalmus, de marzo a septiembre de 2016, recibidas en el Centro de Recuperación y Cribado de Animales Silvestres Universidad Estadual Paulista (UNESP) de la Facultad de Medicina Veterinaria del Campus de Araçatuba. La metodologia utilizada la observación del comportamiento fue el animal focal se obtuvo mediante filmación, haciendo un total de 18 horas/ave, durante tres días consecutivos, utilizando el método físico y cognitivo el primer día; en el segundo lo alimenticio y físico y en el tercero lo sensorial. Los datos fueron analizados inicialmente por la prueba de Shapiro-Wilk y posteriormente por la prueba de Friedman, demostrando que no hubo diferencia significativa ( $p>0.05$ ) en los momentos antes, durante y después del enriquecimiento ambiental, aunque sí hubo una clara percepción de mejora. en el medio ambiente bienestar de las aves.

Palabras clave: Aves salvajes; Comportamiento estereotipado; Bienestar de los animales.

\section{Introduction}

The science of animal welfare has been resting on the scientific scene and establishing itself in all farming systems livestock, pets, work, fish, and wild animals in the wild and in captivity. causing a complex and revolutionary reflection on the way we raise and treat animals. Relevant points related to animal welfare associated with the rearing system and management practices adopted for animals responsible for causing pain and suffering are strongly described in review articles, such as; nutritional management of pregnant sows (Souza, et al., 2021), laying hens, and osteoporosis (Moraes, et al., 2020) as management, transport and high density (Grandin, 2015), battery - cage systems, early weaning, slaughter system. The diagnosis of behavioral abnormalities (etiopathies, psychopathies, sociopathies), one of the most studied being stereotypical conduct, self-mutilation, feather pecking on birds, or excessively aggressive behavior indicates that the animal is under conditions of poor welfare (Fraser, 2009). The lack of stimulation from captivity can lead animals to abnormal and stereotypical behaviors, which indicates poor welfare (Andrade \& Azevedo, 2011). Captive birds can exhibit stereotyped behavior if they self-mutilate, peck at bars and walls, constantly shake their heads, walk around and pluck their own feathers (Mason \&Rushen, 2006). The US Congress significantly revised the Animal Welfare Act in 1985 to include environmental enrichment. The regulations were then implemented in 1991 (Animal and Plant Inspection Service or 'APHIS' 1991) (Nelson \& Mandrell, 2005). Through the revised Animal Welfare Act in 1991, federal legislation required researchers to 'provide a physical environment adequate to promote the psychological well-being of primates' (Lutz Novak, 2005). While birds were not included in this legislation, the revised Animal Welfare Act does give us more reason to evaluate and provide for the mental health of captive avian species (Echols, 2010).

Environmental enrichment is a concept that describes how captive animals' environments can be changed for the benefit of the inhabitants, thus enhancing their welfare (Hill \& Broom, 2009). Environmental enrichment is an example of welfare promotion for captive animals where its application provides opportunities to retain motor skills, and exhibit natural exploratory and predatory behavior, thus improving mental and physiological welfare (Cubas, et al. 2014).

Environmental enrichment consists of introducing activities inside the enclosures with different techniques, divided into five groups: alimentary, sensory, physical, cognitive, and social (Silva \& Macêdo, 2013). Alimentary enrichment consists of providing variations in the feeding of captive animals, sensory enrichment consists in exploring one of the five senses, physical enrichment aims to make the enclosures more similar to the natural habitat, cognitive enrichment awakens the capacity for perception and social enrichment allows interactivity between animals that would normally live in the wild (Militão, 2009).

Cédric \& Marie (2019) affirm that the behavioral approach is based on the principle that all individuals have mechanisms to adapt to their environment to achieve a state of homeostasis (behavioral stability). But if the gap between the animal's actual environment and optimum environment persists, it will tire itself out trying to adapt. Environmental enrichment aims to encourage the animal to perform its natural behavior, including increasing the complexity of the environment, providing quality of management conditions, reducing anomalous and stereotypic behaviors, reducing stress, and disease 
(Militão, 2009). This approach, therefore, consists in ensures that the animal exhibits its full behavioral repertoire even if the captive environment is not visually similar to its wild environment. In this approach, the animal interacts with objects or structures in its environment, even if they are not visually similar to elements that it would encounter in its natural habitat (Cédric \& Marie,2019) However, considering the authors' proposal, we can infer that the motivation provided by enrichment generates well-being once idleness and stress are broken.

Psittacidae are birds that occupy the entire globe, from tropical to cold regions. Brazil is considered the richest country in Psittacidae species with thereabout 80 different species (Sick,1997). They feed on fruits and nuts, live in flocks, and have a characteristic shining plumage. The Psittacara leucophthalmus species has a horn-colored beak and they are predominantly green with some red feathers on the head and neck sides and yellow feathers in the chest region (Patrocínio, 2009). The captive environment tends to be monotonous, predictable, and unchallenging, leading to poor adaptive response (Nolasco \&Paglia 2019). Confinement, where there is an absence of adequate environmental stimuli, can predispose these animals to characteristic conditions of stress, resulting from boredom and frustration, leaving them susceptible to the onset of illnesses (Sfalcin \& Vieira, 2021).

The dynamism of the natural environment is unmatched when compared to captivity, physical factors such as temperature, humidity, lighting, structural characteristics, quantity, and availability of food make the captive environment less stimulating and with lower choice availability. The security against the negative aspects of a natural environment is not offset by the foreknowledge and boredom of captivity (Pizzutto, et. al, 2013). The decrease in idleness suggests a preference for activity-associated behaviors related to interaction with the environmental enrichment provided (Sfalcin \& Vieira, 2021). Then in this context, the development of practices involving environmental enrichment arises to minimize the animal's idleness and suffering as a captive. The purpose of this study is to verify the impact of environmental enrichment in escape-related behavioral stereotypies.

\section{Methodology}

\section{Study Design}

This study corresponds to a master thesis project and is part of the authors' research line analyzed. Were used thirty birds of Psittaciformes genus, Psittacidae family, Psittacara leucophthalmus species, that were admitted to wild animal screening center owned by the university at the time from March to September 2016, brought in by the Environmental Police. All birds of this project were healthy adults or juveniles (without flying ability). Sick or behaviorally impaired birds were excluded from this study.

Each bird was kept in a metal cage of 46x454x58cm (length, depth, height). Inside each cage, there was a perch, a feeder, and a drinker. Water and fruits (banana, apple, papaya, watermelon, orange, and pineapple) were served ad libitum twice a day.

The cages were located within a 318x376x365cm (height, width, and length) room, with two glass windows and a door. Birds were exposed to the sunlight daily through spontaneously ventilated windows that were opened during the day and closed at night.

The focal animal method was used in the experiment (Altmann, 1974) the which one observes only one individual in the group at a time, for a specific period of time and all desired behaviors of each specific category are noted The ethogram considered the expression of behaviors before, during and after the environmental enrichment, according to each behavioral category. The following behavioral categories were considered: locomotion - lateral displacement on the perch (Sgarbiero, 2009) and walking on the floor or on the cage screen (Pimenta, 2009). Maintenance - cleaning the feathers with the beak (Andrade \& Azevedo, 2011), shaking the plumage (Pimenta, 2009), resting on the belly with the head turned back under the 
wing, or on the back, or with closed eyes (Sgarbiero, 2009) resting on the perch (Andrade \& Azevedo, 2011) stopping on the screen (Pimenta, 2009) and stop on cage floor (Sgarbiero, 2009). Alimentary - drink water, climb into the food pot or eat (Prestes, 2000), interactivity with environmental enrichment practice and abnormal behavior (gnaw the perch, the feeder, the cage screen or escape attempts) (Sgarbiero, 2009). The Qualitative Behaviour Assessment (QBA) method was used through the free choice of adjectives for the animals' body expression, known as "Free-choice Profile" (FCP) (Ceballos, 2018).

\section{Data Collection and Analysis}

Individual evaluations were made using a Sony DCR-SR68 camera with a tripod. Each bird was recorded during the day for six uninterrupted hours, during three consecutive days, within a totaling 18 hours/bird. The assessments comprised a period of idleness in the first two hours of observation, the introduction of enrichment in the third and fourth hours, and withdrawal of enrichment in the fifth and sixth hours, with a rotating scheme of procedures as presented in Table 1.

Table 1. Rotating scheme of procedures of environmental enrichment by day, Araçatuba, São Paulo-Brazil, 2016.

\begin{tabular}{ll}
\hline Day & Environmental \\
\hline 1 & Physical and cognitive - toy \\
2 & Feed and physical - Twigs with stuck fruits \\
3 & Sensorial - sounds that mimic the natural habitat \\
& (waterfall, rain, other animals) \\
\hline
\end{tabular}

Source: Authors.

On the first environmental enrichment day, a colorful swing was placed hanging from the top of the cage. On the second day, for alimentary and physical enrichment, a twig with stuck fruits that were typically served in the feeder was introduced. On the third day, sounds were played through a laptop that mimicked the bird habitat.

\section{Statistical Analysis}

A Shapiro-Wilk test was used to study the distributions of variables for normality and a Friedman test was used to quantify the significance between the differences for nonparametric variables, the number of times the behavior was demonstrated, in each behavioral category, in the moments before, during and after the introduction of environmental enrichment. The Biostar 5.0 statistical software was used, considering $\mathrm{p}<0.05$ significance.

\section{Ethical Aspect}

This work was submitted to the Ethics Committee in the Use of Animals of the São Paulo State University (UNESP)Brazil under protocol FOA n ${ }^{\circ}$ 01033-2016 and was approved.

\section{Results}

\section{Student Profile}

The lots of expressions were counted every 10 minutes. After watching one minute of the video, it was registered how many times the behavior happened. Before the enrichment, the most prevalent categories of behavior was maintenance, followed by food, abnormal behavior, and locomotion, as shown in Table 1 During enrichment, there was an increase in the maintenance category, followed by the feeding, abnormal behavior, and locomotion categories, which had decreased expression in relation to the before moment. After enrichment, there was a decrease in locomotion, maintenance, and feeding 
categories, and an increase in the expression of abnormal behavior, however, the maintenance category still was the most observed.

Overall, the highest expression observed category at all moments was maintenance, where the animals clean the feathers with their beaks, shake their plumage, and at resting, which indicates an improvement in the welfare of the birds. The other behavioral categories are in Table 2.

Table 2. Ethogram of white-eyed parakeet showing the number of times the behavior of the behavioral categories were expressed in the different phases (before, during, and after) for each application of environmental enrichment techniques, Araçatuba-São Paulo-Brazil 2016.

\begin{tabular}{lllll}
\hline \multirow{2}{*}{ Behavioral category } & \multicolumn{3}{c}{ Moments } & After \\
\cline { 2 - 4 } Locomotion & Before & During & 148 & 350 \\
Maintenance & 105 & 97 & 498 & 1551 \\
Feeding & 515 & 538 & 215 & 691 \\
Abnormal behavior & 285 & 191 & 168 & 447 \\
Environmental enrichment practice & 163 & 116 & 133 & 0 \\
\hline Total & 0 & 1068 & 1075 & 1029 \\
\hline
\end{tabular}

Source: Authors.

As shown in table 3, no significant statistical differences were observed in the frequency of expressions obtained through the focal animal method at the before, during, and after moments of environmental enrichments $(p>0.05)$.

Table 3. Comparative analysis of behavioral categories, Araçatuba-São Paulo -Brazil 2016.

\begin{tabular}{lc}
\hline Behavioral category & $\mathbf{p}$ \\
\hline Locomotion & 0,09 \\
Maintenance & 0,62 \\
Feeding & 0,05 \\
Abnormal behavior & 0,14 \\
\hline
\end{tabular}

Source: Authors.

\section{Discussion}

The present work shows a small approach to environmental enrichment practices based on the observation of behavior using a defined ethogram. As demonstrated by many laboratory studies, enrichment helps to increase the complexity of the environment. Therefore, enrichment should stimulate the development of the normal behavioral repertoire and reduce or prevent the development of abnormal behavior.

Environmental enrichment increases the captivity complexity, leading to a behavioral flexibility response to dynamic environments, enabling an improvement for biological functionality (Newberry, 1995). The results suggest that birds exposed to the sensorial, alimentary, physical, and cognitive enrichment showed a welfare improvement, aiding the recovery for later release. Although the results were not statistically significant, the visual perception, through the QBA method, of well-being 
improvement was clear, where the animals were less agitated, did not try to escape, and decreased stereotyped behavior in general.

Stress indicators, such as feather plucking and attempted escapes were observed during the three periods of the experiment. Well-being indicators, such as play with the toy, locomotion, and feather cleaning were similar to Maciel, et al. (2010) observations, where they demonstrated in their work with Psittacidaes that the use of enrichment favored greater activity, stimulating the natural behaviors of the species.

Rivera (2006) demonstrated that positive social stimulation in laboratory rats indicates that, regardless of the species, sociable animals need to maintain their natural habits in order to maintain high well-being, showing that the interaction of animals in relation to enrichment is a positive practice when applied to animals that have a natural intra and interspecies relationship.

Our observation results verified that there was no statistically significant difference between the observed behavioral categories, however, it was visually clear the improvement of the bird welfare, similar to the results expressed by Andrade \& Azevedo (2011), with true parrots The reduction of escape behavior was similar to that reported in Mason \& Rushen (2006), and there were no deaths, which was frequently observed in the period before the study was conducted. Although we do not use cortisol biomarkers to assess stress in captive birds, there was a clear lack of activity to increase surveillance activity, aggressive behavior, agonists, and stereotypies that are also associated with stress (Morgan \& Tromborg, 2007).

The biggest obstacle encountered during this research was to find healthy birds that could be released after the study since most of the animals that arrived at Wild Animal Recovery and Screening Center were mutilated or with behavioral alterations, originating from the captivity or trafficking, unable to be released, regardless of rehabilitation. Currently, screening centers and zoos develop periodic protocols with environmental enrichment practices for animals in an attempt to minimize the stress of captivity.

The behavioral repertoire expressed by the birds is complex and the animal's interaction with the environment during captivity requires an adaptation that if motivation is not offered to the animal, and/or sensory stimuli may occur, consequently stereotypical due to stress.

The study of animal behavior in the face of environmental enrichment practices is of great value to be adopted in rehabilitation and triage centers, parks and zoos, in order to create adequate environments that allow animals to express their natural behaviors.

The use of environmental enrichment for animals should become a common practice. It is necessary for further studies the elaboration of strategy models and the larger number of captive species, aiming to prove the importance of improving animal welfare. The welfare in captivity is a great challenge to be overcome, for professionals in this field. Having to adapt to a diversity of stressor stimuli may bring with it important biological expenses for technical, physiological, and behavioral aspects of these animals (Pizzutto, et al., 2013). Environmental enrichment is an important tool to improve the quality of life of the animal in captivity, reducing stress and idleness. Reese, et al. (2021) in the face of such a scenario, the only reasonable approach is science-based animal welfare assessment. Increasing public concern about animal welfare, however heartening, must act as the catalyst for a scientific endeavor and not be the platform for fundamental change.

\section{Conclusion}

We conclude that environmental enrichment brought benefits to the birds, the release period was anticipated and, consequently, there was less interference with the bird's natural behavior. Future studies should be carried out with the aim of better understanding the influence of enrichment on animal welfare in captive birds. 


\section{References}

Altmann, J. (1974). Observational Study of Behavior: Sampling Methods. Behavior, 49 (3/4):227-267.

Andrade, A. A, \& Azevedo, C. A. (2011) Efeitos do enriquecimento ambiental na diminuição de comportamentos anormais exibidos por papagaiosverdadeiros (Amazona aestiva, Psittacidae) cativos. Revista Brasileira de Ornitologia.19 (1):56-62.

Ceballos, M. C. \& Sant 'Anna, A.C. (2018 ).Evolução da ciência do bem-estar animal: Uma breve revisão sobre aspectos conceituais e metodológicos. Revista Acadêmica Ciência Animal DOIhttp://dx.doi.org/10.7213/1981-4178.2018.161103.Available

https://periodicos.pucpr.br/index.php/cienciaanimal/article/view/23740

Cédric Sueur† \& Marie Pelé† (2019). Animal welfare:from science to law, XVIII Influence of living nvironment for the welfare of captive animals: behavious and enrichment. (Le bien-être animal: de la science au droit) edição: Schweitzer Louis, Hild Sophie Capítulo: XVIII

Editora:L'Harmattanhttps://www.researchgate.net/publication/328602173_Importance_of_the_environment_for_the_welfare_of_captive_animals_behaviours_ and_enrichment\#fullTextFileContent

Cubas, Z. S., Silva, J. C. R. \& Catão-Dias, J. L. (2014). Tratado de Animais Selvagens: Medicina Veterinária. 2nd ed. São Paulo: Roca; 2. P

Echols M. S. (2010). Captive bird welfare and enrichment (PART 1) The Medical Center for Birds Oakley, AAVAC/UEPV Annual Conference Hobart USA https://www.aavac.com.au/files/2010-19.pdf

Fraser, D. (2009). Can we measure distress in animal? Ethology of non human animals 1-9.

Grandin, T. (2015). Improving Animal Welfare. In: Temple Grandin (Ed.). A Practical approach. Colorado: Cabi. 328p.

Hill, S. P. \& Broom, D. M. (2009). Measuring zoo animal welfare: theory and practice. Zoo Biology. (28):531-544.DOI: 10.1002/zoo.20276 3

Lutz, C. K. \& N. M. A. (2005). Environmental Enrichment for Nonhuman Primates: Theory and Application ILAR journal 46, (2): 178-191. doi: 10.1093/ilar.46.2.178.

Maciel, D. M. R., Saraiva, P. D. L., Martins, P. S., Travenzoli, N. M. \& Menezes, T. P. (2010). Estudo e enriquecimento ambiental com psitacídeos do centro de biodiversidade da USIPA (CEBUS). In: $11^{\text {a }}$ Semana de Iniciação Científica e $2^{\text {a }}$ Semana de Extensão - Unileste MG "Educação com competência e respeito à vida."; Coronel Fabriciano.

Mason, G. \& Rushen, J, (2006). Stereotypic Animal Behaviour: Fundamentals and Applications to Welfare. 2nd ed. Wallingford: CAB International; 336 p.

Militão C. (2009). Enriquecimento ambiental Enquadramento e Caracterização;. Zoo-Santo Tirso: Escola Profissional Agrícola Conde de São Bento. São Bento.

Morgan, K. N. \& Tromborg, C. T. (2007) Sources of stress in captivity. Applied Animal Behaviour Science. (102), p. $262-302$.

Moraes, J. E., de, Borges, M.R., Amoroso, L., Reis, T.L., Calixto, L.F.L., Lagassi, T.C., Duarte, K.M.R. \& Pizzolante, C.C. (2020) Bien estar de gallinas ponedoras y la osteoporose. Pesquisa, Sociedade e Desenvolvimento , [S. 1.] , 9, (3), pág. e150932588,. DOI: 10.33448 / rsd-v9i3.2588.

Nelson, R. J., Mandrell, T. D. (2005). Enrichment and nonhuman primates: "First, do no harm". ILAR Journal 46(2), $171-177$.

Newberry, R. C. (1995). Environmental enrichment: Increasing the biological relevance of captive environments. Applied Animal Behaviour Science. 44 (24):229-243

Nolasco, V. N. \& Paglia, K. L. G. (2014). Aplicação do Enriquecimento Ambiental Alimentar e Sensorial para Callithrix penicillata (E. Geoffroy, 1812) em cativeiro. Acervo da Iniciação Científica https://www.metodista.br/revistas/revistas- izabela/index.php/aic/article/view/627

Patrocínio, D. N. M. (2009). Bichos do Paraná: Guia da Fauna Paranaense. Curitiba: Governo do Paraná, IAP-Instituto Ambiental do Paraná;. 243 p.

Pimenta, F. R. P., Soares, A. D. S, Freitas, M. L. P, Santos, M. S. V., Martins-Hatano, F., Bidard, A. M. \& Perini, E. S. (2009). Estudo comportamental de um casal de arara-azul-grande, Anodorhynchus hyacinthinus (LATHAM, 1790) mantidas em cativeiro no parque zoobotânico Vale na floresta nacional de Carajás, Pará, Brasil. In: IX Congresso de ecologia do Brasil; São Lourenço. 1-4 p.

Pizzutto, C. S., Scarpelli, K. C., Rossi, A. P., Chiozzotto, E. N.\& Leschonski, C. (2013). Bem-estar no cativeiro: um desafio a ser vencido. Rev. Educ. Cont. Med. Vet. Zootec. 11(2):6-17. https://www.revistamvez- crmvsp.com.br/index.php/recmvz/article/view/16218.

Prestes, P.N. (2000). Descrição e análise do etograma de Amazona pretrei em cativeiro. Revista Brasileira de Ornitologia 22;8(12):25-42. Available from: http://revbrasilornitol.com.br/BJO/article/view/1204. 
Reese, L., Ladwig-Wiegard, M. Fersen, L., Haase, G.,Will,H., Merle, R., Encke, D. , Maegdefrau, H., Baumgartner, K. \& Thöne-Reineke, C. (2020) Deflighting zoo birds and its welfare considerations. Animal Welfare. (29): 69-80. doi: 10.7120/09627286.29.1.069

Rivera, E.A.B. (2006). Estresse em animais de laboratório. In: Andrade A, Pinto S.C. \& Oliveira, R.S. Animais de Laboratório: criação e experimentação. Rio de Janeiro: Fiocruz;. p. 263-273.

Sfalcin, I. C. \& Vieira, Â. D H. N. (2021). Preliminary observation of occupation of Nymphicus Hollandicus under physical environmental enrichment in domestic cattle. Brazilian Journal of Development. 7, (5): 51654-51663. DOI:10.34117/bjdv7n5-521

Sgarbiero, T. (2009). Etograma como ferramenta de avaliação do enriquecimento ambiental para a conservação ex-situ de Ara macao (Linnaeus, 1758) e Ara ararauna (Linnaeus, 1758) no zoológico Municipal de Piracicaba - SP [Trabalho de Conclusão de Curso]. Sorocaba: Universidade Federal de São Carlos; Bacharelado em Ciências Biológicas.

Sick, H. (1997). Ornitologia Brasileira. 2nd ed. Rio de Janeiro: Nova Fronteira; 1862 p.

Silva, A. T. \& Macêdo M. E. (2013). A importância do enriquecimento ambiental para o bem-estar dos animais em zoológicos. Acervo da Iniciação Científica 14;(2) https://www.metodista.br/revistas/revistas-izabela/index.php/aic/article/view/501

Souza, R. G.,Gomide, A. P. C., Feitosa, T. J. O., Silva, M. N. J., Vasconcelos, I.F.F. , França, V.S.,Oliveira, N.C., Santos, J.F.N. \& Silva, I.E. (2020). Bemestar e manejo nutricional de porcas gestantes: uma breve revisão. Pesquisa, Sociedade e Desenvolvimento, 9 (4),52942829,. DOI: 10.33448 / rsd-v9i4.2829. https://rsdjournal.org/index.php/rsd/article/view/2829. 